\title{
Orphan nuclear receptor Nur77 Inhibits Oxidized LDL-induced differentiation of RAW264.7 murine macrophage cell line into dendritic like cells
}

\author{
Liu-hua Hu', Ying Yư ${ }^{\dagger}$ Shu-xuan Jin, Peng Nie, Zhao-hua Cai, Ming-li Cui, Shi-qun Sun, Hua Xiao, Qin Shao,
} Ling-hong Shen ${ }^{*}$ and Ben He*

\begin{abstract}
Background: Nur77 is an orphan nuclear receptor expressed in human atheroma. In vascular cells in vitro, Nur77 expression is induced by pro-inflammatory factors, such as oxidized LDL (oxLDL).

Methods: We analyze the role of Nur77 in the oxLDL-induced differentiation of macrophages into dendritic cells (DC). The murine RAW264.7 macrophage cell line was stably transfected with expression plasmids encoding either GFP or GFP fusions with either full-length Nur77 (GFP-Nur77), Nur77 lacking the DNA binding domain (GFP-Nur77- $\triangle \mathrm{DBD}$ ) or Nur77 lacking the transactivation domain (GFP-Nur77- $\triangle T A D$ ).

Results: GFP-Nur77 overexpression significantly suppressed the effect of oxLDL treatment on DC morphologic changes, expression of DC maturation markers, endocytic activity, allogeneic activation of T cell proliferation, and the activity and secretion of pro-inflammatory cytokines. Analysis of GFP-Nur77- $\triangle T A D$ and GFP-Nur77- $\triangle D B D$ indicated that the Nur77 DNA binding and transactivation domains were both required for this effect. GFP-Nur77- $\triangle D B D$ consistently had the opposite effect to GFP-Nur77, increasing DC-type differentiation in all assays. Interestingly, GFP-Nur77- $\triangle$ DBD protein was cytosolic, whereas GFP-Nur77 and GFP-Nur77- $\triangle T A D$ were both nuclear.
\end{abstract}

Conclusions: These data show that GFP-Nur77 inhibited differentiation of oxLDL-treated macrophages into DC. The effects of Nur77 on the macrophage phenotype may involve changes in its subcellular distribution.

Keywords: Nuclear receptor, Nur77, Oxidized LDL, Macrophage, Dendritic cell

\section{Background}

Atherosclerosis is a chronic inflammatory disease of the arterial wall. From the first appearance of fatty streaks through to the development of advanced atheromatous plaques, atherosclerosis involves interactions between the immune system and metabolic risk factors. The immune and inflammatory actions of monocytes/macrophages play an important role in this disease [1-3]. Peripheral blood monocytes enter the arterial tunica intima, where they differentiate into macrophages or immature dendritic cells (DC) that differentiate fully after exposure to environmental factors [4]. We have shown in vitro that oxidized low-density lipoprotein (oxLDL) stimulates mature

\footnotetext{
*Correspondence: rjshenlinghong@126.com; rjheben@126.com

${ }^{\dagger}$ Equal contributors

Department of Cardiology, Renji Hospital, Shanghai Jiaotong University

School of Medicine, Shanghai 200127, People's Republic of China
}

macrophages to differentiate into DC [5], a process that might be important for inflammatory and immune responses within the atheroma. Although there is currently no in vivo evidence for macrophage-DC differentiation, the functional consequences of this event might significantly exacerbate inflammation in the atheroma. The molecular mechanisms underlying macrophage-DC differentiation is essential for our understanding of atherogenesis and the development of novel drug therapies.

The orphan nuclear receptor Nur77, also known as NR4A1, NGFI-B or TR3, is a member of the steroid/thyroid hormone nuclear receptor superfamily, and was first identified as an early response gene to growth factor stimulation. These nuclear receptors are all transcription factors characterized by three main functional domains: 
a DNA-binding domain (DBD), which is flanked by an amino-terminal transactivation domain, and a carboxyterminal hetero-dimerization and ligand binding domain. Nur77 is an orphan receptor since no specific ligands have been identified. Previous studies have identified diverse roles for Nur77 in cell proliferation, differentiation and apoptosis, as well as neuroendocrine regulation, neurological disorders, liver regeneration and cancer. Nur77 is expressed in human atherosclerotic lesions, and can be induced in human smooth muscle cells, macrophages and endothelial cells [6,7]. Pei LM et al. [8] found that many inflammatory stimuli, including oxLDL, elevate expression of Nur77 in macrophages in vitro, and we have found that Nur77 is upregulated in macrophages exposed to oxLDL [5].

Here, we have used in vitro approaches to investigate a possible role for Nur77 in oxLDL-induced macrophageDC differentiation. We show that overexpression of Nur77 significantly inhibited the differentiation into DC of the RAW264.7 macrophage cells exposed to oxLDL. Analysis of deletion mutants of Nur77 indicated that the Nur77 DNA binding and transactivation domains were both required for this suppressive effect.

\section{Results \\ Establishment of stable RAW264.7 cell lines expressing GFP-Nur77 and GFP-Nur77 deletion mutants}

We have shown previously that macrophages exposed to oxLDL in vitro differentiate into mature DC. Here, we have investigated a possible role for the orphan nuclear receptor Nur77 on the differentiation of oxLDL-treated RAW264.7 cells, a murine macrophage cell line. Nur77, a steroid/thyroid hormone nuclear receptor superfamily, contains three characteristic functional domains involved in transactivation, DNA binding, and ligand binding (Figure 1A). We established clonal RAW264.7 cell lines stably expressing either wild-type GFP-Nur77 or GFP fusion proteins with Nur77 lacking either the transactivation or DNA binding domains (GFP-Nur77- $\triangle \mathrm{TAD}$ and GFP-Nur77- $\triangle \mathrm{DBD}$, respectively). GFP-Nur77 expression was 3-4 fold the level of endogenous Nur77 (Figure 1B). The two deletion mutants of Nur77 were expressed to similar extents (Figure 1C). Fluorescent microscopy revealed that GFP-Nur77- $D$ DBD was cytosolic, whereas GFP-Nur77 and GFP-Nur77- $\triangle$ TAD were strictly nuclear (Figure 1D) suggesting that DNA binding is required for nuclear localization.

\section{Nur77 inhibits the differentiation of oxLDL-treated RAW264.7 cells}

We tested the effects of oxLDL on the morphology, DC surface marker expression, endocytic activity, allostimulatory activity, and cytokine secretion of the RAW264.7 stable cell lines. Consistent with previous results, $72.50 \%$ of GFP control cells had DC morphology after oxLDL treatment as determined by increased cell size, the presence of multiple prominent cytoplasmic processes, and prominent nucleoli (Figure 2A and B). In contrast, although most GFP-Nur77-expressing cells increased in size, only $28.94 \%$ had DC morphology following oxLDL treatment. In contrast, $72.30 \%$ oxLDL-treated GFP-Nur77- $\triangle$ TAD or $82.8 \%$ of oxLDL-treated GFPNur77- $\triangle \mathrm{DBD}$ cell lines were of DC morphology, which was similar to control GFP-expressing cells $(p>0.05)$. There was a small but statistically significant increase in the proportion of DCs in GFP-Nur77- $\triangle D B D$ cells compared to GFP-expressing cells ( $p<0.05$; Figure 2A,B). To determine whether endogenous Nur77 played a role in macrophage-DC differentiation, we used siRNAs to deplete Nur77 and assayed the effect on oxLDL-induced morphological changes. Transfection of Nur77 siRNA successfully depleted endogenous Nur77 in RAW264.7 cells compared to the scrambled siRNA (Figure 2C) and led to a $17 \%$ increase in the proportion of cells with DC morphology following oxLDL treatment compared to that in the scrambled siRNA group ( $66.5 \pm 12.4 \%$ vs. $83.8 \pm$ $12.1 \%, p<0.05$; Figure 2D,E).

To provide definitive evidence to the observed morphology, CD209 was tested by confocal microscopy. (Detailed descriptions of the materials and experimental methods are available in Additional files 1 and 2).

\section{Nur77 inhibits phenotypic changes in oxLDL-treated RAW264.7 cells}

The changes in cell morphology described above suggest that Nur77 inhibits oxLDL-induced RAW264.7 cell differentiation into DCs through its DNA binding and transactivation domains. To investigate this possibility, we evaluated phenotypic changes in oxLDL-treated RAW264.7 cells stably expressing Nur77 and Nur77 mutant proteins by flow cytometry using specific antibodies against co-stimulatory molecules, antigen-presenting molecules, and markers of DC activation. Following oxLDL treatment, the levels of CD40, CD86, CD83, MHC class II, and CD1d were reduced by $62.4 \%, 44.69 \%, 51.7 \%, 55.2 \%$, and $53.29 \%$, respectively, in RAW264.7 cells stably expressing GFP-Nur77 protein compared with those in GFP-expressing cells. However, there was little difference in the levels of these proteins when comparing cells expressing either GFP-Nur77- $\triangle$ TAD or GFP-Nur77- $\triangle \mathrm{DBD}$ with GFP-expressing cells, with the exception that GFPNur77- $\triangle \mathrm{DBD}$ cells had a small but significant increase in the expression of CD83, MHC class II molecules, and CD1d ( $p<0.05$ compared to control cells; Figure 3A). Moreover, all of the aforementioned proteins were significantly up-regulated in Nur77-depleted RAW264.7 cells 


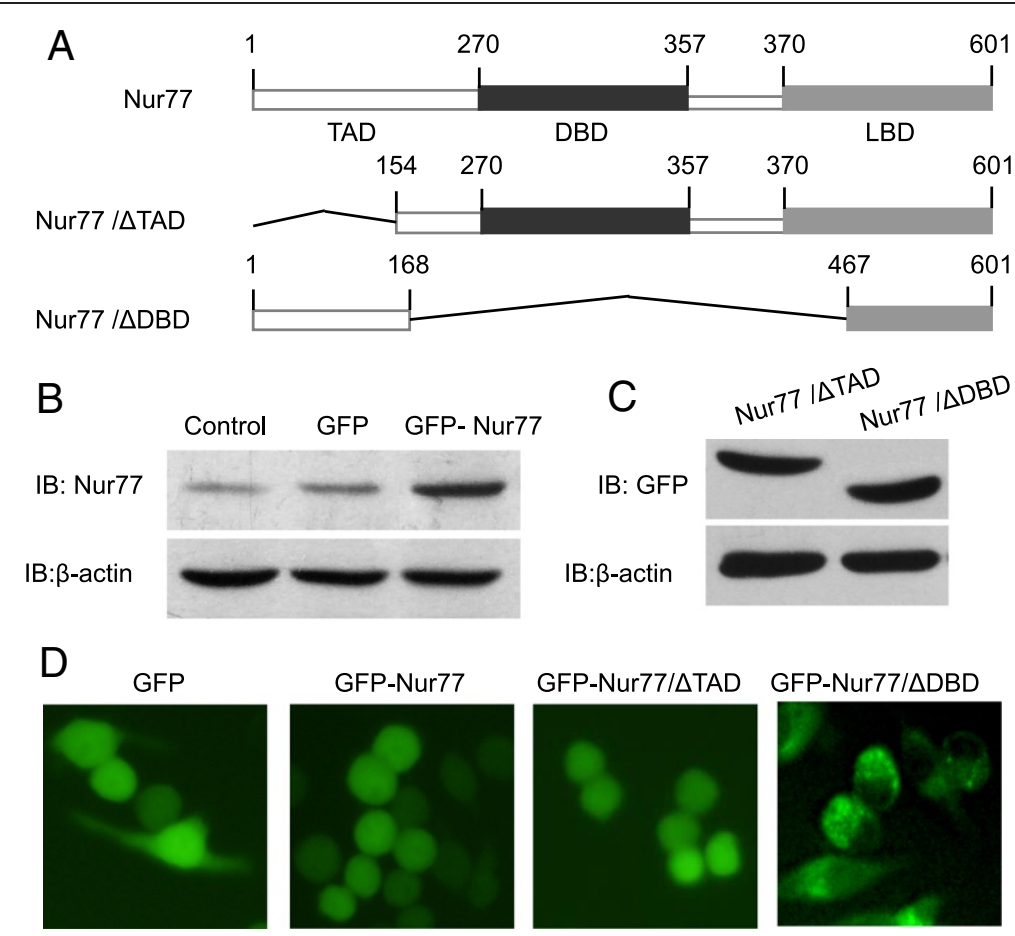

Figure 1 Characterization of stable RAW264.7 cell lines expressing Nur77 and Nur77 deletion mutants. (A) Schematic structure of the Nur77 gene and deletion mutants lacking either the transactivation domain (TAD) or DNA binding domain (DBD). (B) Expression of Nur77 protein in untransfected RAW264.7 cells and in RAW264.7 cell lines expressing GFP or GFP-Nur77. Expression of GFP-Nur77 is 3-4-fold higher than endogenous Nur77 in untransfected or GFP-transfected cells. (C) Expression of GFP-Nur77- $\triangle T A D$ and GFP-Nur77- $\triangle D B D$ fusion proteins in stably transfected RAW264.7 cells. $\beta$-actin expression was used to control for protein loading. A representative of three separate experiments is shown. (D) Subcellular localization of GFP-Nur77, GFP-Nur77- $\triangle T A D$, and GFP-Nur77- $\triangle D B D$ in RAW264.7 cells.

when compared to control cells transfected with scrambled siRNA $(p<0.05$; Figure 3B).

\section{Nur77 decreased endocytosis in oxLDL-treated RAW264.7 cells}

We have previously shown that oxLDL-treated RAW264.7 cells gain several of the functional characteristics of mature DC [5]. Therefore, we next assayed the role of Nur77 in these oxLDL-induced functional changes. Using LY uptake as a marker of endocytosis (Figure 4A), we found that a large proportion of the four stable RAW264.7 cell lines were LY + following $12 \mathrm{~h}$ exposure to oxLDL. Consistent with published results, oxLDL had a dynamic effect on endocytosis. GFP-expressing controlcells exhibited decreased LY uptake by approximately $33 \%$ at $24 \mathrm{~h}$ and $57 \%$ at $48 \mathrm{~h}$ after oxLDL treatment. Similar results were obtained from GFP-Nur77- $\triangle \mathrm{TAD}$ and GFP-Nur77$\triangle \mathrm{DBD}$-expressing cells, except that at $48 \mathrm{~h} \mathrm{LY}$ uptake by GFP-Nur77- $\triangle \mathrm{DBD}$-expressing cells was $15 \%$ lower than GFP-expressing cells. In contrast, oxLDL had little effect on LY uptake in GFP-Nur77-expressing cells at either $24 \mathrm{~h}$ or $48 \mathrm{~h}$. These results indicate that overexpression of Nur77 protein in RAW264.7 cells inhibited the endocytic changes typically displayed by mature DCs, and that this inhibition was dependent upon the DNA binding and transactivation domains of Nur77.

Nur77 reduced the stimulatory effect of oxLDL-treated RAW264.7 cells on T cell proliferation

Stimulation of allogeneic $\mathrm{T}$ cell proliferation is an important function of mature DC. Therefore, we evaluated the effect of Nur77 on T cell proliferation. RAW264.7 cells stably expressing either Nur77 or the Nur77 mutant proteins were pretreated with $10 \mu \mathrm{g} / \mathrm{ml}$ oxLDL for $48 \mathrm{hrs}$ and then cultured with $\mathrm{T}$ cells at a ratio of 1:10 for 5 days. To detect $\mathrm{T}$ cell proliferation, we monitored BrdU incorporation as a measure of cells entering $\mathrm{S}$ phase. In the absence of oxLDL, there was no $\mathrm{T}$ cell proliferation in any of the four stable cell lines. OxLDLtreated GFP-expressing control cells effectively induced the proliferation of $\mathrm{T}$ cells, as did GFP-Nur77- $\triangle \mathrm{TAD}$ expressing and GFP-Nur77- $\triangle \mathrm{DBD}$-expressing cells. In contrast, $\mathrm{T}$ cell proliferation in co-cultures with GFPNur77-expressing cells was approximately one third of the other cell lines (Figure 4B). These results are consistent with an inhibitory role for Nur77 in this T cell assay, possibly through reduced expression of co-stimulatory molecules. 


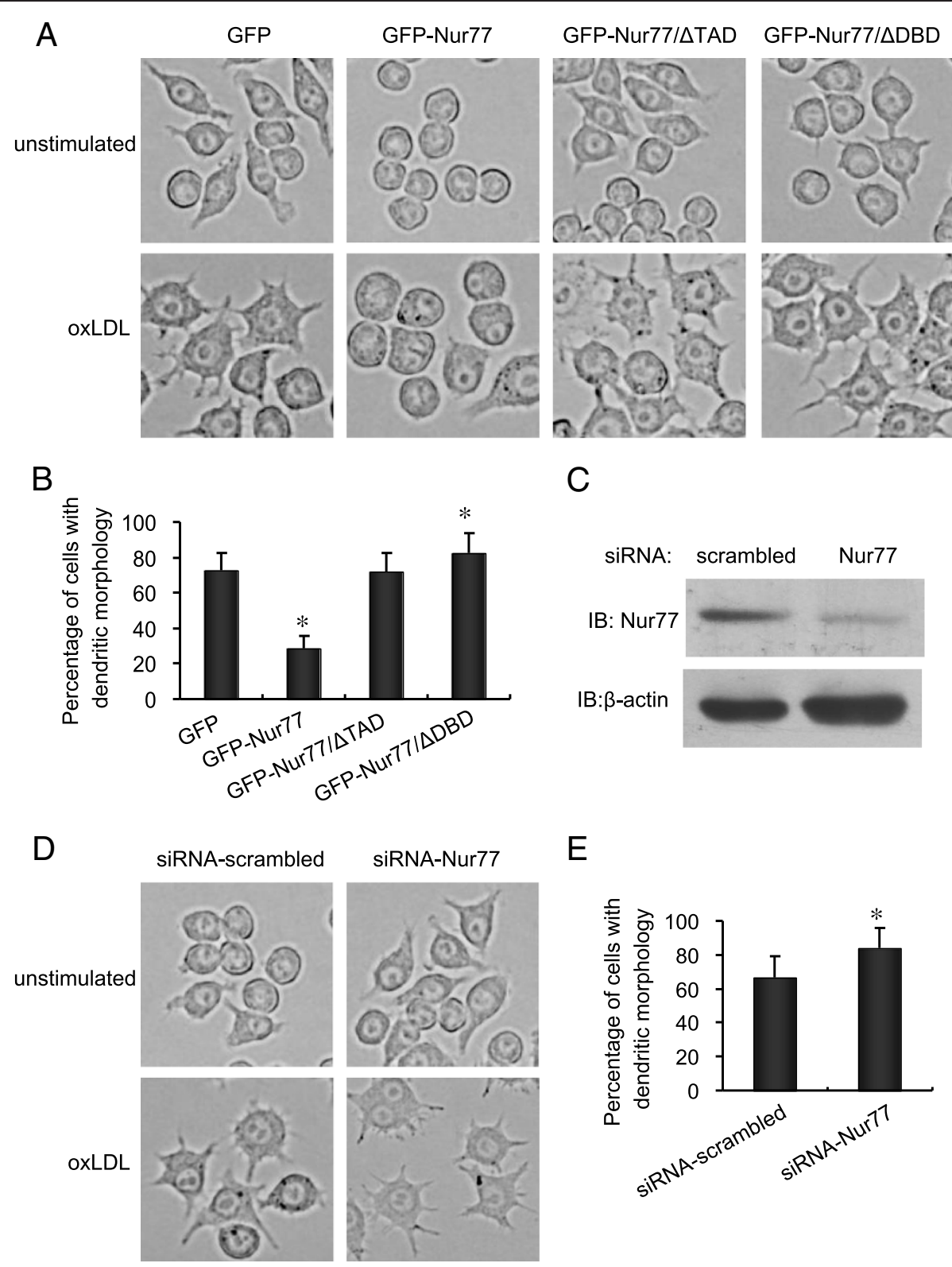

Figure 2 Nur77 inhibits DC morphological changes in oxLDL-treated RAW264.7 cells. (A) RAW264.7 cells stably expressing GFP-Nur77, GFP-Nur77- $\triangle T A D$, or GFP-Nur77- $\triangle \mathrm{DBD}$ were treated with oxLDL $(10 \mu \mathrm{g} / \mathrm{ml})$ for $48 \mathrm{~h}$ and visualized by phase contrast microscopy (400X). Results are representative of three separate experiments. (B) Cells with DC morphology were calculated as the percentage of all cells observed in 10 different fields at $400 \times$ magnification. The bars represent mean \pm SD from three experiments. ${ }^{*} p<0.05$ compared with GFP-expressing control. (C) Western blots showing endogenous Nur77 in RAW264.7 cells $48 \mathrm{~h}$ after transfection with either scrambled siRNA or Nur77 siRNA. Similar results were obtained in three separate experiments. (D) Phase contrast images showing the morphology of oxLDL-treated RAW264.7 cells transfected with either scramble siRNA or Nur77 siRNA. Cultured cells were visualized by phase contrast microscopy as described in (A) and cells with DC morphology were calculated as described in (B). (E) * $p<0.05$ compared with scrambled control.

\section{Nur77 reduced cytokine secretion by oxLDL-treated RAW264.7 cells}

Finally, we assayed the effect of Nur77 on cytokine secretion by oxLDL-treated RAW264.7 cells. Here we show that, IL-12 and TNF- $\alpha$ from oxLDL-treated GFPNur77 cells were decreased to $46.8 \%$ and $41.5 \%$, respectively, compared with that from GFP-expressing control cells. In contrast, expression of the Nur77 mutant proteins did not decrease oxLDL-induced IL-12 and TNF- $\alpha$ secretion. GFP-Nur77- $\triangle \mathrm{DBD}$-expressing cells demonstrated a $24.9 \%$ and $12.7 \%$ increase in IL-12 and TNF- $\alpha$ secretion, respectively (Figure $5 \mathrm{~A}, \mathrm{C}$ ). These data show that Nur77 had an inhibitory effect on cytokine secretion, which required the Nur77 DNA binding domain 
A

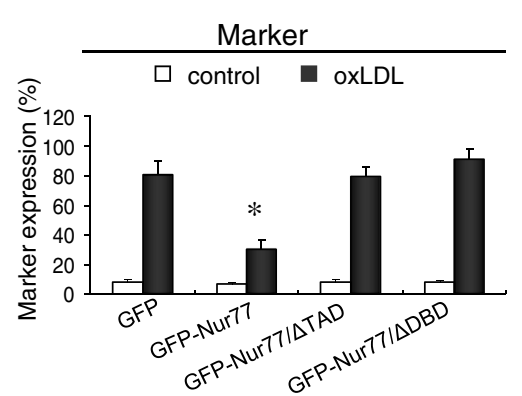

CD40
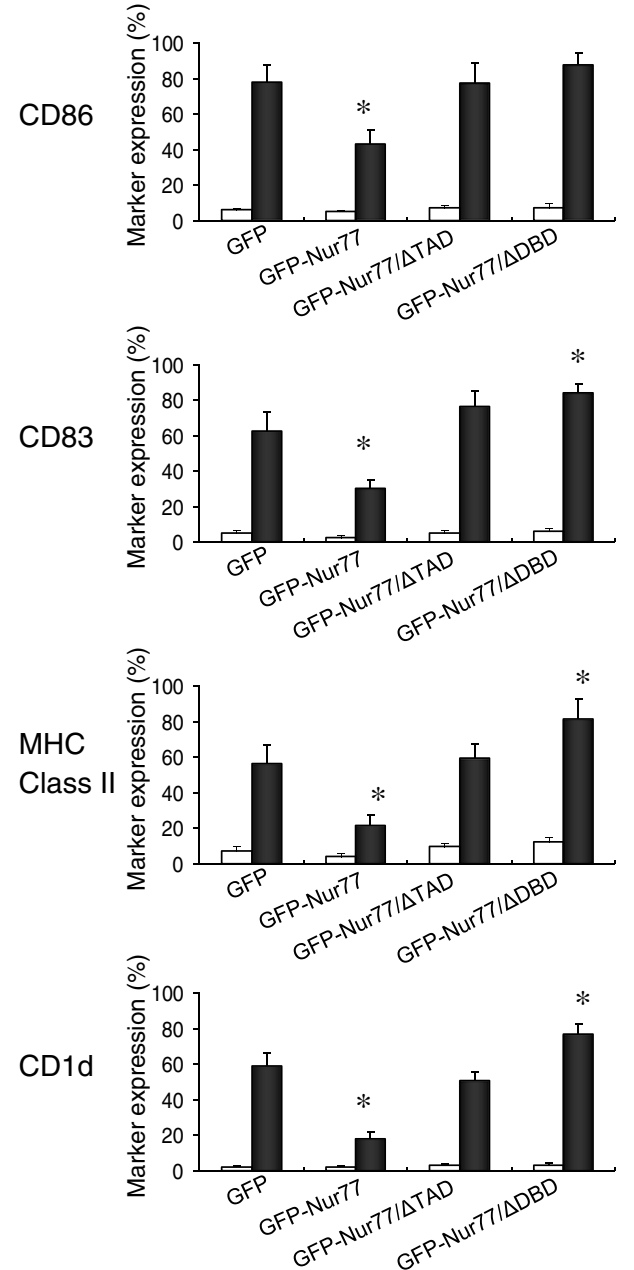

B

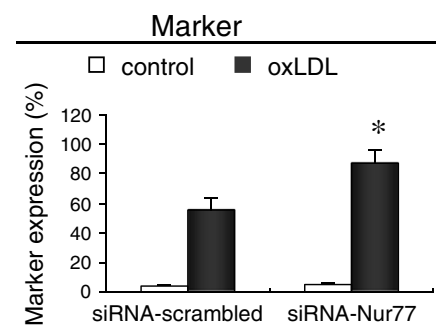

CD86

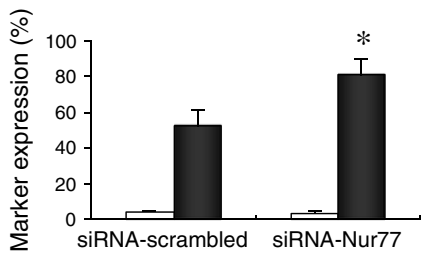

CD83

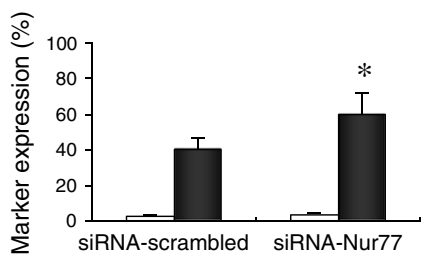

$\mathrm{MHC}$

Class II

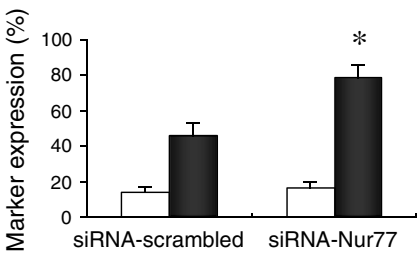

CD1d

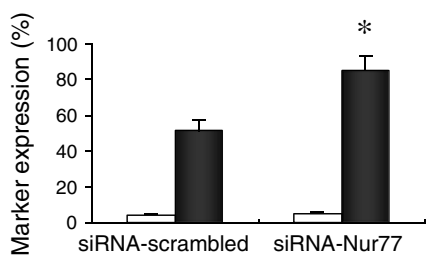

Figure 3 Flow cytometry analysis of the cell surface phenotype of oxLDL-treated RAW264.7 cell lines. (A) Expression of CD40, CD86, CD83, MHC Class II, and CD1d in RAW264.7 cells lines treated with oxLDL for $48 \mathrm{~h}$. Mean \pm SD of three independent experiments is shown. ${ }^{*} p<0.05$ compared with GFP-expressing control. (B) Expression of CD40, CD86, CD83, MHC Class II, and CD1d in RAW264.7 cells transfected with either scrambled siRNA or Nur77 siRNA and stimulated with oxLDL for 48 h. ${ }^{*} p<0.05$ compared with scrambled control.

and transactivation domains. To test the ability of producing several cytokines by these cells, we also analyzed TNF- $\alpha$ and IL-12 including a stimulated control with LPS in GFP-expressing control cells. Results showed that both of the two cytokines can be stimulated by LPS and the levels were 3-fold higher than by the stimulation with oxLDL (TNF- $\alpha$ : $490.12 \pm 14.14 v s .125 .60 \pm 7.07 \mathrm{ng} / \mathrm{ml}$; IL-12: $15.47 \pm 0.28$ vs. $4.15 \pm 0.21 \mathrm{pg} / \mathrm{ml}$ ) (Figure 5B,D).

\section{Discussion}

Dendritic cells are the most potent of all antigenpresenting cells, and play a key role in vascular inflammation and immune activation [9]. OxLDL is a particularly potent inducer of inflammation during the development of atherosclerosis [10,11]. Here, we have shown that Nur77 is likely to play an inhibitory role in DC differentiation. We found that overexpression of Nur77 in a 

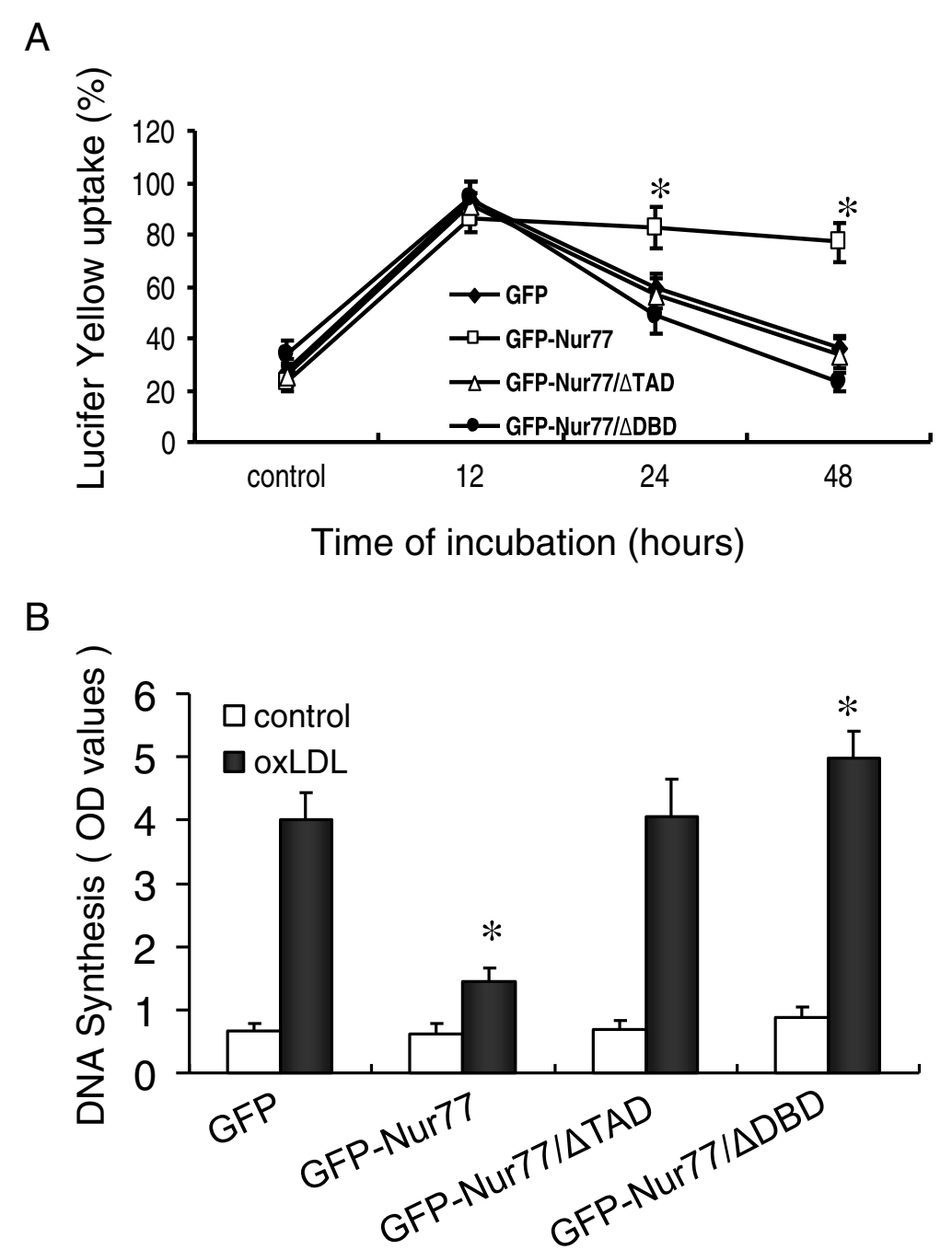

Figure 4 Nur77 enhanced the endocytic activity but suppressed the DNA synthesis of RAW264.7 treated by oxLDL. (A) Flow cytometry analysis of endocytic activity using lucifer yellow (LY) uptake by oxLDL-treated RAW264.7 cells stably expressing GFP-Nur77, GFP-Nur77- $\triangle T A D$, or GFP-Nur77- $\triangle \mathrm{DBD}$. Mean \pm SD of three independent experiments is shown. ${ }^{*} \mathrm{p}<0.05$ compared with GFP-expressing control. (B) Flow cytometry analysis of BrdU incorporation by co-cultures of allogeneic T cells and RAW264.7 cells stably expressing either GFP, GFP-Nur77, GFP-Nur77- $\triangle T$ TAD, or GFP-Nur77- $\triangle \mathrm{DBD}$. Mean \pm SD of three independent experiments is shown. ${ }^{*} p<0.05$ compared with GFP-expressing control.

macrophage cell line, RAW264.7, prevented differentiation into mature DCs following oxLDL treatment, whereas siRNA-mediated Nur77 depletion had the opposite effect. Consistent with this, constitutive expression of Nur77 in vivo decreases immune cell development and maturation. Together, these data suggest that endogenous Nur77 may have an inhibitory effect on macrophage activation and immunity. Many studies of vascular cells also suggest a protective role for Nur77 in atherogenesis [12-14]. For example, overexpression of Nur77 in arterial smooth muscle reduces the formation of smooth musclerich lesions [13]. In addition, in vitro assays have demonstrated that Nur77 significantly reduces the inflammatory response and lipid-loading of human macrophages $[15,16]$.
The possible role of Nur77 in endothelial cells remains unclear, however. In human vascular endothelial cells, Nur77 mediates cell cycle arrest through upregulation of p27Kip1 and downregulation of cyclin A [17], whereas others have implicated Nur77 in vascular endothelial growth factor (VEGF)-A-induced angiogenesis $[18,19]$. Thus, the role of Nur77 in human endothelial cell proliferation is controversial. The reasons for these contradictory effects on endothelial cell proliferation are not clear, but similar effects of Nur77 are observed in other cells. For example, Nur77 was originally recognized for its role in cancer cell proliferation [20-22] but was later found to be a potent proapoptotic molecule [23,24]. Extensive evidence indicates that the stimulation of proliferation by Nur77 is a 

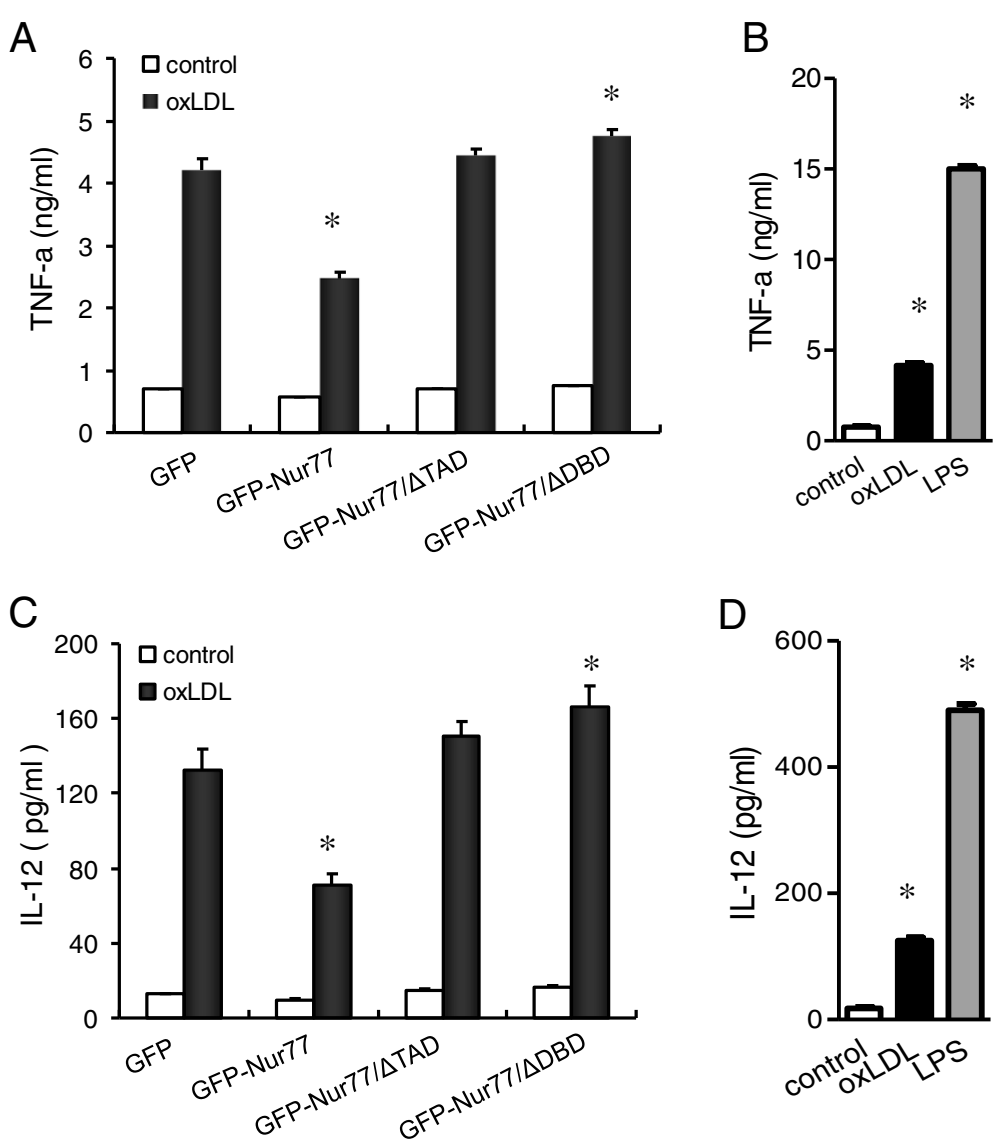

Figure 5 Nur77 overexpression in RAW264.7 cells reduces oxLDL-induced inflammatory cytokine synthesis. Sandwich ELISA analysis of TNF-a (A) and IL-12 (C) for the supernatants of oxLDL-treated RAW264.7 cells stably expressing GFP, GFP-Nur77, GFP-Nur77- $\triangle$ TAD or GFP-Nur77$\triangle \mathrm{DBD}$. Data represent mean $\pm \mathrm{SD}$ of three independent experiments for $1 \times 10^{6}$ cells, ${ }^{*} p<0.05$ compared with GFP-expressing control cell. (B) and (D) showed the level of TNF-a and IL-12 in GFP-expressing control cells with or without stimulated by oxLDL or LPS, respectively. The bars represent mean \pm SD from three experiments. ${ }^{*} p<0.05$ compared with control cells.

transcriptional effect, based on the observations that the DNA binding and transactivation domains were both required [25]. We have also found that the transcriptional activity of Nur77 is required for suppression of macrophage activation [16]. Thus, we were interested in whether the inhibitory effect of Nur77 on oxLDL-induced macrophage differentiation was also dependent upon its transcriptional activity. Consistent with this, expression of GFP-Nur77 $\triangle T$ TAD had no significant effect on the induction of DC differentiation by oxLDL compared with expression of GFP alone. In contrast, expression of GFP-Nur77- $\triangle$ DBD caused a modest but significant increase in the proportion of cells with DC morphology and functionality.

The subcellular distribution of the GFP-Nur77 fusion proteins is consistent with a transcriptional role for Nur77 because GFP-Nur77- $\triangle$ DBD was mainly cytosolic, whereas GFP-Nur77 and GFP-Nur77- $\triangle$ TAD were nuclear. These observations suggest that Nur77 protein may induce the differentiation of macrophages into DC when it is localized in the cytosol. Although it is not known if oxLDL induces the nuclear export of Nur77 in macrophages, there is evidence from cancer cells that Nur77 can be induced to translocate from the nucleus to the cytosol and that this confers important biological functions, including apoptosis and differentiation.

\section{Conclusion}

the differentiation of macrophages into DC following exposure to oxLDL can be suppressed by the transcriptional activity of Nur77. The effect of Nur77 on macrophage differentiation may be related to changes in its subcellular location. Nur77 might induce macrophage-DC differentiation when it localized in the cytosol. Further studies are needed to understand the relationship between the subcellular location of Nur77 and its protective effect against atherosclerosis. 


\section{Methods}

\section{Lipoprotein isolation and oxidation}

LDL $(\mathrm{d}=1.019-1.063)$ was isolated by sequential ultracentrifugation of EDTA-anticoagulated fasting plasma from healthy normo-lipidemic volunteers. After ultracentrifugation, EDTA was dialyzed at $4^{\circ} \mathrm{C}$ against PBS containing $0.5 \mathrm{mM}$ EDTA. The LDL protein concentration was determined by a modification of the Lowry method, using bovine albumin as the standard. Isolated LDL $(1 \mathrm{mg} / \mathrm{ml})$ was oxidized at $37^{\circ} \mathrm{C}$ for $18 \mathrm{~h}$ in PBS containing $5 \mu \mathrm{M} \mathrm{CuSO}_{4}$. Oxidation reactions were terminated by the addition of EDTA $(0.3 \mathrm{mM}, \mathrm{pH} 8.5)$ and butylated hydroxytoluene $(40 \mu \mathrm{M})$. Modified LDL was dialyzed extensively at $4^{\circ} \mathrm{C}$ against PBS containing $0.5 \mathrm{mM}$ EDTA, and the oxLDL preparations were sterilized by membrane filtration $(0.45 \mu \mathrm{m})$ and stored in the dark at $4^{\circ} \mathrm{C}$. All lipoprotein preparations were tested for endotoxin using an endotoxin assay kit (Sigma, St. Louis, MO).

The study protocol were approved by the Ethics Committee of Renji Hospital, School of Medicine, Shanghai Jiao tong University and complied with the National Regulations on the Use of Clinical Samples in China. These volunteers provided written informed consent to Ethics Committee for research purpose.

\section{Cell culture}

RAW264.7 cells were obtained from the American Type Culture Collection, and grown at $37^{\circ} \mathrm{C}, 5 \% \mathrm{CO}_{2}$ in DMEM containing penicillin $(100 \mathrm{U} / \mathrm{ml})$, streptomycin $(100 \mu \mathrm{g} / \mathrm{ml})$, and $10 \%$ heat-inactivated fetal calf serum.

\section{Plasmid and transient transfection of RAW264.7 cells}

The GFP-Nur77 expression plasmid (pGFP-Nur77), GFPNur77- $\triangle$ TAD and GFP-Nur77- $\triangle \mathrm{DBD}$ were gifts from X-K. Zhang (Burnham Institute, La Jolla, CA). RAW264.7 cells were plated into 6 -well plates, $1 \times 10^{6}$ cells per well, incubated overnight, then transfected with Lipofectamine 2000 (Invitrogen, USA) and $7.5 \mu \mathrm{g}$ DNA per well, according to the manufacturer's instructions.

\section{Establishment of stable clones expressing GFP-Nur77, GFP-Nur77- $\triangle T A D$, and GFP-Nur77- $\triangle D B D$}

pGFP-Nur77, pGFP-Nur77- $\triangle T A D, p G F P-N u r 77-\triangle D B D$, and the $p G F P$-control vectors were introduced into RAW264.7 cells as described [5]. Transfected cells were allowed to recover for $24 \mathrm{~h}$, followed by drug selection

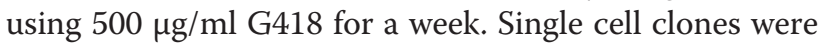
identified by serial dilution in 96 well plates. Clonal RAW264.7 cell lines stably transfected with pGFP-Nur77, pGFP-Nur77- $\triangle$ TAD, pGFP-Nur77- $\triangle \mathrm{DBD}$ or $p G F P$ vectors were incubated in medium containing $200 \mu \mathrm{g} /$ ml G418. Overexpression of GFP-Nur77, GFP-Nur77$\triangle \mathrm{TAD}$ and GFP-Nur77- $\triangle \mathrm{DBD}$ were confirmed by fluorescent microscopy and western blot analysis.

\section{siRNA transfections}

The following small interfering RNAs (siRNAs; Dharmacon Research Inc.) were used: Nur77, 5'-CAG UCC AGC CAU GCU CCU C dTdT-3'; scrambled siRNA, 5'-GCG CGC TTT GTA GGA TTC G dTdT-3'. siRNAs were transfected $(10-\mu \mathrm{l}$ aliquot of $20 \mu \mathrm{M}$ siRNA/well) into individual wells of 6-well plates using Oligofectamine (Invitrogen), according to the manufacturer's protocol. Two days after transfection, cells were harvested for analysis.

\section{Western blotting}

Cells were lysed in $150 \mathrm{mM} \mathrm{NaCl}, 10 \mathrm{mM}$ Tris (pH 7.5), 5 mM EDTA, 1\% Triton X-100, 1 mM PMSF, $10 \mathrm{mg} / \mathrm{ml}$ leupeptin, $10 \mathrm{mg} / \mathrm{ml}$ pepstatin, and $10 \mathrm{mg} / \mathrm{ml}$ aprotinin for $30 \mathrm{~min}$ on ice. Equal amounts of lysates $(50 \mu \mathrm{g})$ were separated by $8-12 \%$ SDS-PAGE and transferred onto Immobilon-P transfer membranes (Millipore, Billerica, MA). Non-specific binding sites were blocked by incubating membranes in $5 \%(\mathrm{w} / \mathrm{v})$ solution of nonfat dried milk in TBST (50 mM Tris- $\mathrm{HCl}$ (pH 7.4), $150 \mathrm{mM}$ $\mathrm{NaCl}, 0.1 \%$ Tween 20). Blocked membranes were probed with specific antibodies against Nur77 (1;1000, Abcam, Cambridge, UK), GFP (1;1000, eBioscience, San Diego, CA), or $\beta$-actin (1;5000, BioVision, Mountain View, CA) in TBST. Membranes were washed 3 times with TBST and then incubated for $2 \mathrm{~h}$ at room temperature in TBST containing HRP-linked anti-rabbit or anti-mouse immunoglobulin. After 3 washes in TBST, HRP was visualized by chemiluminescence using the ECL kit (Chemicon, Temecula, CA). The protein concentration was quantified using the BCA protein assay (Merck, Darmstadt, Germany).

\section{Phenotypic analysis by flow cytometry}

Cells were incubated for 30 min with Phycoerythrin (PE)labeled monoclonal antibodies recognizing either CD40, CD83, CD86, MHC Class II, or CD1d (eBioscience), washed with staining buffer, and analyzed by flow cytometry on a FACSCalibur (BD Biosciences, Franklin Lakes, NJ).

\section{Analysis of endocytic activity}

Endocytosis was measured after treatment with oxLDL $(10 \mu \mathrm{g} / \mathrm{ml})$ for the indicated times. Cells were incubated at $37^{\circ} \mathrm{C}$ for $30 \mathrm{~min}$ with Lucifer Yellow (LY; $1 \mathrm{mg} / \mathrm{ml}$; Sigma-Aldrich), and washed 3 times at $4^{\circ} \mathrm{C}$ with cold PBS containing $1 \%$ BSA and $0.05 \%$ NaN3. Cells were analyzed on a FACSCalibur (BD Biosciences).

\section{T cell proliferation assay}

The effect on allogeneic $\mathrm{T}$ cell proliferation of oxLDLtreated RAW264.7 cells was measured as described [13]. Briefly, T cells were purified from the spleens of C57BL/ 6 mice using nylon wool columns. RAW264.7 cells 
grown in 96-well tissue culture plates were treated with oxLDL for $48 \mathrm{~h}$ and then treated with mitomycin $\mathrm{C}$ $(50 \mu \mathrm{g} / \mathrm{ml})$ for $1 \mathrm{~h}$. Afterwards, a total of $1 \times 10^{5} \mathrm{~T}$ cells were added as responders. The cell mixtures were cultured for 5 days and $20 \mu \mathrm{l}$ diluted BrdU was added $18 \mathrm{~h}$ prior to the end of the incubation period according to the procedure recommended by the manufacturer (Chemicon). The plates were analyzed using a spectrophotometer microplate reader with the absorbance set at $450 \mathrm{~nm}$ (MK3, Thermo, USA).

\section{Cytokine assays}

GFP-expressing RAW264.7 cells were stimulated by LPS ( $5 \mu \mathrm{g} / \mathrm{ml}$, Sigma) or oxLDL $(10 \mu \mathrm{g} / \mathrm{ml})$ for $24 \mathrm{~h}$, and secretion of IL-12 or TNF- $\alpha$ into the supernatant was analyzed using cytokine specific ELISA kits according to manufacturer instructions (BD Bioscience).

\section{Statistical analysis}

Data were expressed as mean $\pm \mathrm{SD}$. One way-ANOVA. When more than two groups were involved in analysis, Dunnett test was used for comparison of difference between two groups. Comparisons with $p<0.05$ were considered statistically significant. Comparisons with $\mathrm{p}<0.05$ were considered statistically significant.

\section{Additional files}

\section{Additional file 1: Supplemental materials and methods.}

Additional file 2: Figure S1. Nur77 inhibits DC-specific marker CD209 changes in oxLDL-treated RAW264.7 cells. (A) RAW264.7 cells stably expressing GFP, GFP-Nur77, GFP-Nur77- $\triangle T A D$ or GFP-Nur77- $\triangle D B D$ were treated with oxLDL $(10 \mu \mathrm{g} / \mathrm{ml})$ for $48 \mathrm{~h}$ and visualized by fluorescent microscopy (200X). Results are representative of three separate experiments. (B) Cells with CD209 positive staining were calculated as the percentage of all cells observed in 10 different fields at 200x magnification. The bars represent mean \pm SD from three experiments. ${ }^{*} p<0.05$ compared with GFP-expressing control cells.

\section{Abbreviations \\ oxLDL: Oxidized LDL; DC: Dendritic cells; DBD: DNA-binding domain; GFP-Nur77: GFP fusions with either full-length Nur77; GFP-Nur77- $D$ DBD: Nur77 lacking the DNA binding domain; GFP-Nur77- $\triangle T A D$ : Nur77 lacking the transactivation domain; VEGF: Vascular endothelial growth factor.}

\section{Competing interests}

The authors declare that they have no competing interests.

\section{Authors' contributions}

$\mathrm{HLH}$ and $Y Y$ participated in analysis and involved in drafting the manuscript, interpretation of data. CZH and NP carried out cell culture and plasmid transient transfection. CML and SSQ participated in western blotting and cell phenotypic analysis by flow cytometry. XH performed analysis of endocytic activity and T cell proliferation assay. SQ tested cytokine secretion and JSX performed the statistical analysis. SLH and HB conceived of the study, participated in its design and and helped to draft the manuscript. All authors read and approved the final manuscript.

\section{Acknowledgements}

Funding: This work was supported by the Grant Numbers 30800453, 30971185, $81370399,81070239,81100200,81100199,81270374$ and 81170192 from the National Natural Science Foundation and the Grant Numbers 10JC1409400,
11JC1407100, 11ZR1421600 and 12140902600 from the Shanghai Municipal Natural Science Foundation. The funders had no role in study design, data collection and analysis, decision to publish, or preparation of the manuscript.

Received: 4 April 2014 Accepted: 3 November 2014

Published online: 29 November 2014

\section{References}

1. Dahl TB, Arne Y, Mona S, Erik O, Arve D, Annika M, Damås JK, Tunheim SH, Thor U, Camilla S, Bjørn B, Serena T, Lars G, Frøland SS, Kirsten K-S, David R, Pål A, Bente H: Increased Expression of Visfatin in Macrophages of Human Unstable Carotid and Coronary Atherosclerosis: Possible Role in Inflammation and Plaque Destabilization. Circulation 2007, 115(8):972-980. 27.

2. Parks BW, Lusis AJ: Macrophage accumulation in atherosclerosis. N Engl J Med 2013, 369(24):2352-2353.

3. Frostegård J: Immunity, atherosclerosis and cardiovascular disease. BMC Med 2013, 11:117.

4. Yuri V: Bobryshev. Dendritic cells and their role in atherogenesis. Lab Invest 2010, 90:970-984.

5. Shen LH, Zhou L, Wang BY, Pu J, Hu LH, Chai DJ, Wang L, Zeng JZ, He B: Oxidized low-density lipoprotein induces differentiation of RAW264.7 murine macrophage cell line into dendritic-like cell. Atherosclerosis 2008, 199:257-264.

6. Pang T, Wang J, Benicky J, Saavedra JM: Minocycline ameliorates LPS-induced inflammation in human monocytes by novel mechanisms including LOX-1, Nur77 and LITAF inhibition. Biochim Biophys Acta 2012, 1820(4):503-510.

7. Wang L, Gong F, Dong X, Zhou W, Zeng Q: Regulation of vascular smooth muscle cell proliferation by nuclear orphan receptor Nur77. Mol Cell Biochem 2010, 341(1-2):159-166.

8. Pei L, Castrillo A, Chen M, Hoffmann A, Tontonoz P: Induction of NR4A orphan nuclear receptor expression in macrophages in response to inflammatory stimuli. J Biol Chem 2005, 280(32):29256-29262. 12.

9. Alberts-Grill N, Denning TL, Rezvan A, Jo H: The role of the vascular dendritic cell network in atherosclerosis. Am J Physiol Cell Physiol 2013, 305(1):C1-C21.

10. Gómez M, Vila J, Elosua R, Molina L, Bruguera J, Sala J, Masià R, Covas MI, Marrugat J, Fitó M: Relationship of lipid oxidation with subclinical atherosclerosis and 10-year coronary events in general population. Atherosclerosis 2014, 232(1):134-140.

11. Leibundgut G, Witztum JL, Tsimikas S: Oxidation-specific epitopes and immunological responses: Translational biotheranostic implications for atherosclerosis. Curr Opin Pharmacol 2013, 13(2):168-179.

12. Arkenbout EK, de Waard V, van Bragt M, van Achterberg TA, Grimbergen JM, Pichon B, Pannekoek H, de Vries CJ: Protective function of transcription factor TR3 orphan receptor in atherogenesis: decreased lesion formation in carotid artery ligation model in TR3 transgenic mice. Circulation 2002, 106(12):1530-5. 17.

13. Bonta PI, van Tiel CM, Vos M, Pols TW, van Thienen JV, Ferreira V, Arkenbout EK, Seppen J, Spek CA, van der Poll T, Pannekoek H, de Vries CJ: Nuclear receptors Nur77, Nurr1, and NOR-1 expressed in atherosclerotic lesion macrophages reduce lipid loading and inflammatory responses. Arterioscler Thromb Vasc Biol 2006, 26(10):2288-2294.

14. McMorrow JP, Murphy EP: Inflammation: a role for NR4A orphan nuclear receptors? Biochem Soc Trans 2011, 39(2):688-693.

15. Hu LH, He B, Shen LH, Zhou L, Pu J, Jiang LS, Shao Q, Wang L, Zeng JZ: Nuclear receptor Nur77 inhibits oxidized low density lipoprotein induced lipid loading in macrophages. Zhonghua Xin Xue Guan Bing Za Zhi 2008, 36(11):1032-1036.

16. Shao Q, Shen LH, Hu LH, Pu J, Qi MY, Li WQ, Tian FJ, Jing Q, He B: Nuclear receptor Nur77 suppresses inflammatory response dependent on COX-2 in macrophages induced by oxLDL. J Mol Cell Cardiol 2010, 49(2):304-311.

17. Arkenbout EK, van Bragt M, Eldering E, van Bree C, Grimbergen JM, Quax PH, Pannekoek H, de Vries CJ: TR3 orphan receptor is expressed in vascular endothelial cells and mediates cell cycle arrest. Arterioscler Thromb Vasc Biol 2003, 23(9):1535-1540.

18. Zeng H, Qin L, Zhao D, Tan X, Manseau EJ, Van Hoang M, Senger DR, Brown LF, Nagy JA, Dvorak HF: Orphan nuclear receptor TR3/Nur77 regulates VEGF-A-induced angiogenesis through its transcriptional activity. J Exp Med 2006, 203(3):719-729.

19. Zhao D, Qin L, Bourbon PM, James L, Dvorak HF, Zeng H: Orphan nuclear transcription factor TR3/Nur77 regulates microvessel permeability by 
targeting endothelial nitric oxide synthase and destabilizing endothelial junctions. Proc Natl Acad Sci U S A 2011, 108(29):12066-12071.

20. Páez-Pereda M, Kovalovsky D, Hopfner U, Theodoropoulou M, Pagotto U, Uhl E, Losa M, Stalla J, Grübler Y, Missale C, Arzt E, Stalla GK: Retinoic acid prevents experimental Cushing syndrome. J Clin Invest 2001, 108(8):1123-1131.

21. To SK, Zeng WJ, Zeng JZ, Wong AS: Hypoxia triggers a Nur77- $\beta$-catenin feed-forward loop to promote the invasive growth of colon cancer cells. Br J Cancer 2014. Epub ahead of print].

22. Yu L, Su YS, Zhao J, Wang H, Li W: Repression of NR4A1 by a chromatin modifier promotes docetaxel resistance in PC-3 human prostate cancer cells. FEBS Lett 2013, 587(16):2542-2551.

23. Luciano F, Krajewska M, Ortiz-Rubio P, Krajewski S, Zhai D, Faustin B, Bruey J-M, Bailly-Maitre B, Lichtenstein A, Siva Kumar K, Satterthwait AC, Xiao-Kun Z, Reed JC: Nur77 converts phenotype of $\mathrm{BCl}-\mathrm{B}$, an antiapoptotic protein expressed in plasma cells and myeloma. Blood 2007, 109(9):3849-3855.

24. Thompson J, Burger ML, Whang H, Winoto A: Protein kinase $\mathrm{C}$ regulates mitochondrial targeting of Nur77 and its family member Nor-1 in thymocytes undergoing apoptosis. Eur J Immunol 2010, 40(7):2041-2049.

25. Davis IJ, Hazel TG, Chen RH, Blenis J, Lau LF: Functional domains and phosphorylation of the orphan receptor Nur77. Mol Endocrinol 1993, 7(8):953-964.

doi:10.1186/s12865-014-0054-z

Cite this article as: Hu et al:: Orphan nuclear receptor Nur77 Inhibits

Oxidized LDL-induced differentiation of RAW264.7 murine macrophage cell line into dendritic like cells. BMC Immunology 2014 15:54.

\section{Submit your next manuscript to BioMed Central and take full advantage of:}

- Convenient online submission

- Thorough peer review

- No space constraints or color figure charges

- Immediate publication on acceptance

- Inclusion in PubMed, CAS, Scopus and Google Scholar

- Research which is freely available for redistribution 